\title{
Second Generations of Foreign Origin
}

\author{
Written by Nasara Cabrera Abu
}

This document discusses the theme of second generations of immigrant origin. First, we reflect on the "second generation" concept itself before moving on to a contextualisation of second generations in international, Spanish and Canarian migration studies. We then present a brief characterisation of one part of the second generations in the Canary Islands, and we consider the most relevant social issues involved in this reality. We end by outlining some brief conclusions.

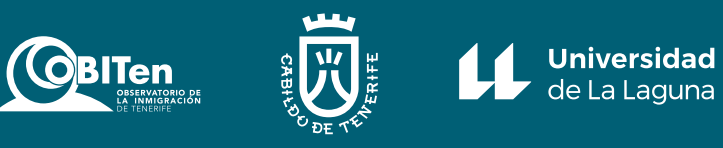




\section{Introduction: Is the term second generations appropriate?}

The literature on migration uses second generation to refer to "young people born in Spain to foreign parents or brought to the country before the age of 12" (Portes and Aparicio, 2013 , p. 1). Children who come with their parents at an early age and experience most of their primary socialisation in their new society are also known as generation 1.5 (Aparicio, 2007). The term "second generation" is widely used in studies on the children of immigrants to refer to them. However, these people never migrated, although in many cases they maintain the foreign nationality inherited from their parents.

It is important to point out the difference between the second generation of immigrant origin and young immigrants. The first category refers to a generational cohort that descends from individuals who emigrated to a society other than their society of origin. Therefore, the second generation would be their descendants, who were either born in the society to which their parents emigrated, or in which they arrived as children and where part of their socialisation took place. By contrast, we refer to young immigrants when they moved from their place of origin to another location after their 12th birthday, which places them in a social category that is equivalent to a specific age range within given population group.

Some studies suggest that the term "second generation of immigrants" creates a symbolic border between the group of immigrants and their children on the one hand, and the native population on the other. In other words, "it relies on a classification that equates the children of immigrants with their parents, in opposition to the native population" (García Borrego, 2003 , p. 2). In this regard, it behooves us to recall the normally pejorative burden that the term immigrant implies, and that, therefore, also plays a stigmatising role for those who are included in the same group. Accordingly, the natural question to ask is, When does someone stop being an immigrant? Why are the children of immigrants identified as "children of"? According to García Borrego (2003), characterising a population based on its parentage is bordering on a form of cultural racism.

Elsewhere, Aparicio and Tornes (2007, p. 23) propose that such a concept not be viewed in biological terms, but in historical-political terms: in historical terms because they are second generations that are separated in time with respect to sectors of the population prior to them, meaning they face different situations that must be understood; and politically because if they were not considered from this perspective, "the generational specifics of the current minority descendants of immigrants would be neglected".

Beyond their symbolically important and sociologically necessary conceptualisation, there are multiple issues related to the culturally diverse generations that reside in Canarian society in general, and in Tenerife in particular, that must be emphasised in order to understand and address the current situation in our societies. What has been studied about them? What are their sociodemographic characteristics? What other social issues are behind these realities? or, How is cultural diversity being managed today in society and in educational institutions? We will attempt to answer all these questions in the sections that follow. 


\section{The study of second generations}

Studies on second generations began to proliferate in Spain in the first decade of the 21st century. However, research in the field is scarce, as is the empirical bibliography on the matter. This it is not surprising, since Spain became a country of immigration later than others, such as the United States or other European countries, where such studies began earlier. In the United States, the existing social rifts created by racial issues and the role of schools as a melting pot began to be questioned starting in the 1950, and took hold in the 1960s (Aparicio, 2007). In some European countries, such as Germany and France, concerns over the integration of second generations of foreign origin came to the fore when events occurred that jeopardised the prospects of peaceful coexistence and citizen security.

And thus, studies on second generations were first undertaken in the United States, and later exported to Europe in the 1990s and to Spain in the first decade of the new millennium. Moreover, the North American and European studies address different concerns. In the United States, they are based on the failure to meet the country's expectations (the American dream), while in Europe they have to do with more "immediate and individualistic issues (threats to citizen security and social peace), or with somewhat elitist criteria (the rupture of human rights and the European social model that is supposed to underlie the deficient levels of integration)" (Aparicio and Tornes, 2007, p. 30). However, both approaches end up converging on the importance given to the educational and professional achievements of the second generation to determine their degree of integration.

The theory of segmented assimilation is one of the perspectives currently used in the approach to this reality. This theory eventually replaced the classical theories of assimilation, which viewed as inevitable the tendency that, over time, the host society would cause this assimilation, according to the thesis on the cycle of inter-ethnic relations (Park, 1930). The theory of segmented assimilation, as opposed to the classical theory of assimilation, states that the children of immigrants will follow different paths (more or less social success), and that this will depend on the (social, economic or cultural capital) resources available to both them and their families. This theory also considers the importance of context (perception of the ethno-national group in the host society) and intergenerational relationships.

Among the most relevant European studies, we note the so-called Effectiveness of National Policies in the Integration of Children of Immigrants (EFFNATIS) ${ }^{1}$, published in 2001, which studied integration policies in a series of European countries (France, Germany and Great Britain) and the consequences that these policies had on the integration of the children of immigrants. Its main conclusions can be summarised as follows: first, none of the three national models of integration (the French assimilationist, the British multiculturalist or the German ethnic community) are effective in achieving their goals; second, general policies applied to the entire population are more effective than those specific to a unique group; and third, the educational and professional achievements of the children of immigrants were lower than those of the native population.

Another and more recent comparative study in Europe was called Reducing School Leaving in the European Union ${ }^{2}$, involving nine EU countries with different indicators for early leaving from education and training (ELET). It focused on the role that aspirations and the perceived support from family and school play in this process, and found, in many cases,

1 More information on the project and the final report are available at http://www.efms.uni-bamberg.de/prineffe.htm.

2 More information on the project is available at http://sprc.info/reducing-early-school-leaving-in-europe/. 
the coexistence of high aspirations with exclusionary practices on the part of the teaching staff. In the case of Spain, the study showed one of the highest ELET rates within the EU28 countries, with the greatest gap by gender and country of birth or nationality (Carrasco, Pàmies and Narciso, 2018).

Spain provides the setting for the most important study at the European level in terms of sample size of second generations of foreign origin, and one of the first conducted in this subject at the national level. It was called the Longitudinal Investigation on the Second Generation in Spain (ILSEG), and it was carried out at three different times between 2006 and $2017^{3}$. The study employed a quantitative methodology with surveys of both foreign and native populations, and relied on the segmented assimilation theory approach for its analysis. It considered different variables, some of them structural (sociodemographic (age, marital status, type of residence), education, educational aspirations and language, employment, occupational status and income), and others that were more subjective in nature (perceptions of discrimination and national self-identification).

The results show similarities between the children of immigrants and natives in the variables of ambition for the future, perceptions of discrimination and common national self-identity. The study concludes with a positive balance of the integration process for second generations in Spain. However, there are unfavourable factors for the group descended from immigrants, such as economic disadvantages, more problems being promoted to better jobs and the effect of the Muslim religion in discriminatory experiences (Portes, Aparicio and Haller, 2018, p. 166).

From the study cited above - ILSEG - a subsample was taken of the children immigrants and natives already in the labour market that, together with other qualitative approaches, gave rise to another publication on the integration of second generations into the Spanish labour market and their experiences with discrimination. This report concludes that the group of immigrant origin is at a disadvantage with respect to its native counterparts in terms of the jobs held in the labour market. This fact "would seem to point to the existence of a certain level of discrimination by companies when selecting and hiring young people of immigrant origin" (Aparicio, Biderbost and Tornos, 2019, p. 109).

In the Canarian context, there are no studies that focus on second generations, which are incorporated into analyses involving young immigrants. Bearing this in mind, there are some articles pertaining to the Canarian case on 1) the sociodemographic profile of young people of foreign origin (Domingo and Bayona, 2007), 2) good integration practices, taking as an example the European INVOLVE project, where the Tenerife Immigration Observatory participated as a guest (Fariña Álvarez and Obiten, 2007), and 3) immigration, youth and social planning in the Canary Islands (Kuehn Dumpiérrez, 2007).

Another study conducted in the Canary Islands is the report on Immigration, Schooling and Intercultural Education in the Canary Islands (2007), which addresses the social and academic characteristics of students of immigrant origin, without distinguishing between second generations, in various pre-university educational levels. Its most notable findings include a higher level of school absenteeism among students of immigrant origin compared to native students, a low level of conflict, a lower involvement in extracurricular activities by the group of immigrant origin, the limited support services in some municipalities, and a low level of educational problems, resulting in a high level of integration.

3 The results have been compiled in different publications: Aparicio (2007); Portes, Aparicio \& Haller (2009); Portes \& Aparicio (2013); and Portes, Aparicio \& Haller (2018). 
Finally, and as the only publication that considers the children of immigrants exclusively, an article in the Revista Española de Sociología analyses their academic performance in the Canary Islands with data from PISA and that, in the words of the authors, is a "case ignored by the literature and the only community in which this student body does not exhibit an academic disadvantage" compared to other European countries and to the rest of Spain (Álvarez-Sotomayor, Gutiérres Rubio and Martínez-Cousinou, 2018, p. 83). The article concludes that the Canary Islands is the only region of Spain where the children of immigrants have similar scores to native children in the PISA data, not because the former have better results than their counterparts in other regions (they are actually quite similar), but because of the worse relative performance of Canarian pupils, whose scores are below those in the other regions. The only area that does not exhibit too many differences is that the academic results of the children of immigrants are better than those of the previous generation, although these differences are also smaller compared to the rest of the country.

\section{Characterising second generations in the Canary Islands}

Second generations in the Canary Islands are not a recent phenomenon. There were already children of EU immigrants, primarily Norwegian and Swiss, but also Asians, including Indians, who began to settle in the late nineteenth century; Koreans, who settled around the islands' port activity around the 1960s; and from the Middle East (Palestinians, Syrians, Lebanese), who began to arrive in the first half of the 20th century, as well as immigrants from Mauritania and Western Sahara (related to the suitcase trade). However, the second generation phenomenon has only recently become visible due to the media coverage of it, and especially of unaccompanied foreign minors. One thing that has changed are the nationalities of origin and their percentage of the total foreign population or of foreign origin, which is obviously on the rise.

One of the main problems when studying second generations of foreign origin is the lack of adequate statistical data since, for example, the available data do not make it possible to identify second generations. Therefore, in order to characterise the children of immigrants, we have taken as a data source the number of births in the Canary Islands based on the nationality of the parents ${ }^{4}$. However, these graphs must be taken with some caution, since they do not fully capture the reality of second generations in the Canary Islands either. This is because they do not include people who arrived in the Canary Islands as children, nor population movements (people born in the Canary Islands who left or moved to a place other than the island of birth), nor those born to naturalised parents of foreign origin.

As Graph $1^{5}$, on the trend in births in the Canary Islands to foreign parents, shows, the highest number of births involves foreign parents, both the mother and the father. Secondly are the births in which only the mother is foreign; however, here there is no information to determine the nationality of the father, or even if a father is listed, since they can be single mothers, or the father can be a Spanish citizen or not be in the Canary Islands at the time of birth. Thirdly are the births in which only the father is a foreigner, meaning, therefore, that the mother is a Spanish national (though we do not know if by birth or through nationalisation). In any case, we tried to account for the children both of foreign parents and of culturally mixed couples, although we do not have the data needed to exactly determine

\section{ISTAC data.}

5 No information from the Civil Registries of the municipalities of Antigua (2004), Puerto del Rosario $(2007,2004)$, Yaiza (2004) and Arona (2003 and 2004). This also applies to Figures 3, 5 and 6. 
Number of births in the Canary Islands according to nationality of parents.

Source ISTAC. Birth Rate, Natural Movement.

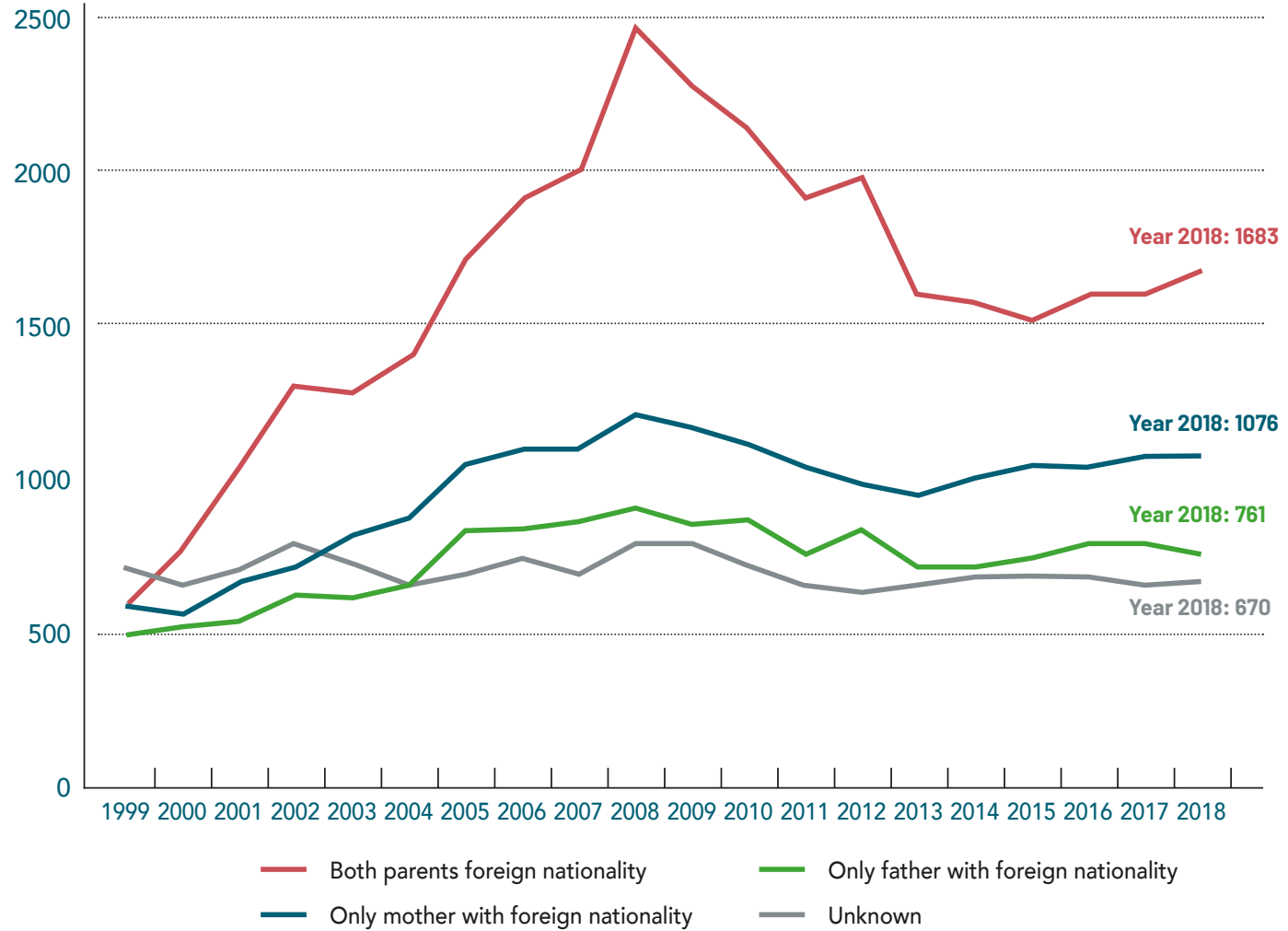

the characteristics of the parents. In the three cases, the year with the highest births was 2008 , with 2,460 babies born to two foreign parents, 1,213 born to a foreign mother, and 907 to a foreign father. After that year, there was a decrease in births, with an uptick in the case of births to two foreign parents and to only foreign fathers in 2012, as well as a slight increase from 2015 through 2018, except in the case of births to only foreign fathers, which fell in 2018 compared to 2017.

Graph 2 shows the proportion of births to foreign mothers and/or fathers compared to births to parents with Spanish nationality. As we can see, the number of births of foreign origin increased over the years, reaching a maximum in 2008, followed by a drop until 2013, after which the figures ticked up until the last year for which data are available. While the births of foreign origin in the Canary Islands in 1999 accounted for $8.9 \%$ of all births, the highest ratio, 22.7\%, was reached in 2009. This was the result of not only a higher number of births of foreign origin, but of a lower number of births of nationals. The highest

Graph 3 ratio, however, was in 2018, when

Percentage of persons aged 20 or less according to the nationality of their mothers (year 2018).

Source

ISTAC. Birth Rate, Natural Movement. this figure reached $23.5 \%$ of total births, which is also related to the reason mentioned above.

The figure below, Graph 3, shows the proportion of the total number of births from 1999 to 2018 in comparison to the population of Spanish nationality born in those years in the Canary Islands. The graph answers the question on the proportion of the population under 20 years of age born in the Canary

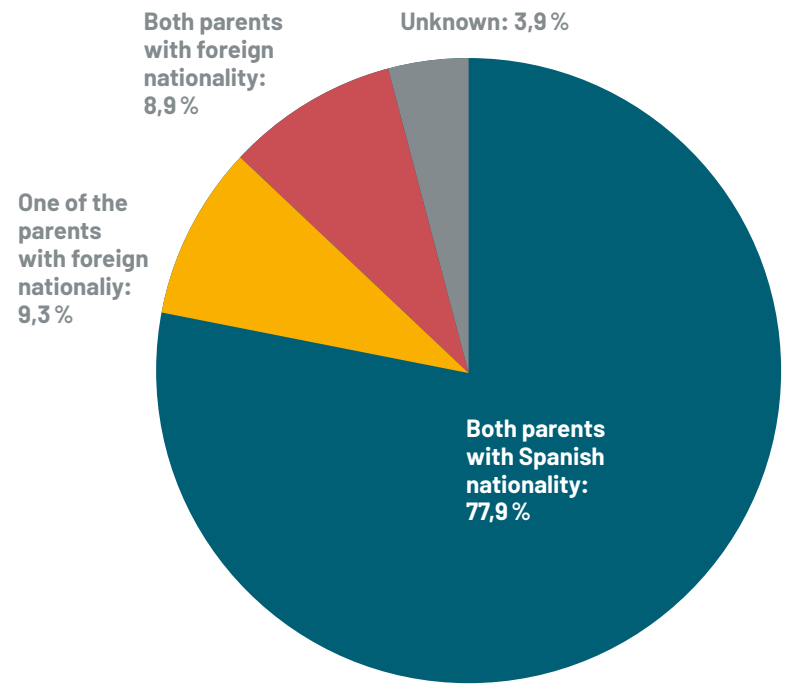




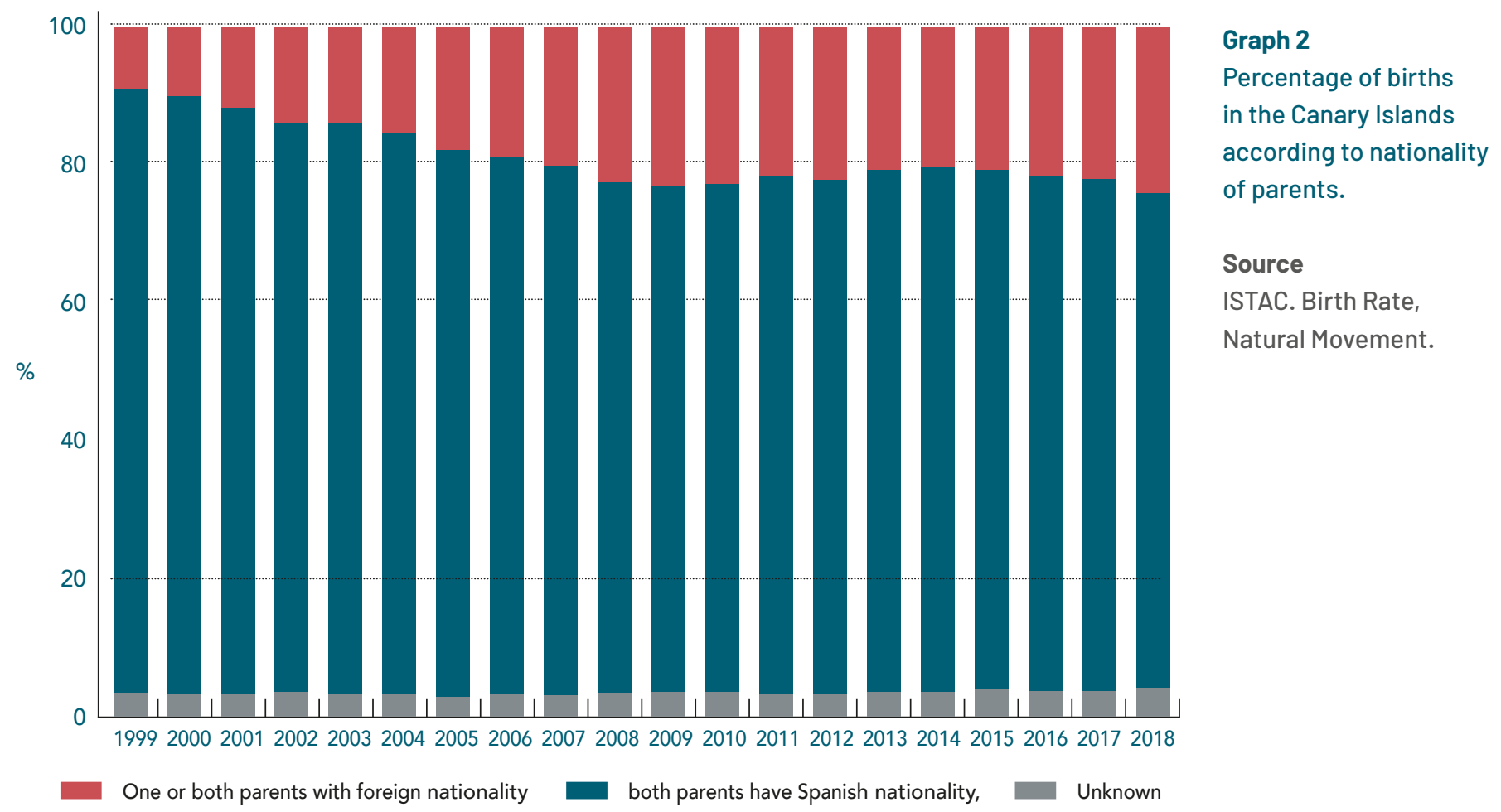

Islands and of foreign origin with respect to the national population. As the graph shows, $77.9 \%$ of the population born in the Canary Islands to Spanish mothers and/or fathers is under 20 years of age, $9.3 \%$ was born into families with one foreign parent, and $8.9 \%$ into families with two foreign parents.

In general, for the period studied (1999-2018), the island with the highest number of births was Tenerife (with 1,500 births), save for 2003 and 2004, when more births were registered in Gran Canaria. Therefore, Gran Canaria ranks second, with 948 births in 2018, followed by Lanzarote (515), Fuerteventura (428), La Palma (91), La Gomera (23) and El Hierro (15). While the birth rate figures from 2008 have not been repeated in Tenerife, or in the rest of the islands, Tenerife, together with Lanzarote and La Palma, saw an increase in 2018 compared to the previous year, while this rate went down in Gran Canaria and Fuerteventura and remained stable in El Hierro and La Gomera.

As for the ancestry of the parents, the majority of the births are registered to mothers from America, and the second largest number of births involves mothers of European origin. The trend in births to African mothers, in third place, has fluctuated, exhibiting a downward trajectory in recent years. Lastly, with the lowest number of births, are the mothers of Asian origin, with fairly stable figures and a downward trend, though this trend has abated since 2014.

\section{0ther relevant questions involving second generations}

Second generations of immigrant origin are usually studied in terms of their integration: what level of education they have completed and what type of occupation they have, all in comparison to the preceding generation so as to conclude the direction of said integration; that is, if they are repeating the same pattern as their parents, improving on it through 
greater educational and/or professional success or if, on the contrary, they are on the path to social exclusion.

However, there are other, no less important, issues that may even be related to social status, but that have more to do with the perceptions, identifications and experiences that second-generation individuals of immigrant origin encounter. In turn, perceptions, identifications and experiences can be related to one another in different ways, as we will see below.

The second generation exhibits the so-called paradox of social integration (Heath, 2014, p. 8). That is, the greater the social integration, the more aware they are of the discrimination they face. This is so because their expectations of acceptance and integration in their place of residence are higher and, on many occasions, they are frustrated by the visible differences with respect to the majority group (identity or cultural markers such as phenotypic traits, clothing and language). Discrimination in the host society negatively influences how individuals identify with their place of residence.

Therefore, the question that must be asked here is to what extent does the origin of second generations condition their life experiences in what they regard as their own society, having been born in it. One possible explanation is that the more evident these identity markers, defined as elements that underscore the differences between these people and the autochthonous group, the more the second generation will experience discrimination, since they will be perceived as "immigrants" despite not actually being so.

These experiences can have consequences that entail, in a way, a self-fulfilling prophecy, since the fact that certain culturally differentiated groups viewing themselves as being outside the boundaries of the group will result in a greater perception of social distancing among the former.

In this regard, some studies have investigated the causes that promote the social isolation of these second generations. Such is the case of the article on the second generation of British Pakistanis in the United Kingdom (Khan, 2011, p. 67). Specifically, the author wonders if the observed identification of these individuals with the place of origin of their families results from the hostility of British society towards the Muslim population, or if, on the contrary, it is their own resistance to assimilation that has caused this distance and hostility with local society. Along these same lines, the author uses the term "reactive ethnicity", coined by Ruben G. Rumbaut (2008), which illustrates how individuals "exposed to the message that, for racial or cultural reasons, they are not part of the mainstream social current" (Portes, Vickstrom and Aparicio, 2013, p. 231) tend to retreat into their ethnic identities (Rumbaut, 2008).

There is another important issue in this area, namely the messaging of the autochthonous population regarding ethnic minorities, and that includes culturally diverse second generations. Messaging that is, in turn, directly related to the perceptions and experiences of people of immigrant origin along the lines commented earlier. Particularly important in this regard is Islamophobia, and specifically gender Islamophobia, since it is the image of young and old women alike wearing headscarves that has fomented much of the Islamophobic phenomenon (Ramírez and Mijares, 2005). Thus, some studies point to greater discrimination against Muslim women with hijabs, given the greater visibility of a stigmatised cultural identity (Aixelá, 2001). In the specific case of second-generation Muslim women, they are viewed from an ethnocentric approach that strips them of their social value (Goffman, 1986) and, consequently, of their status as citizens. As a result, they 
are not recognised as equals. On many occasions, this hostile messaging towards them is legitimised through democratic values such as gender equality that are theoretically opposed to the practice of "veiling", which makes them targets of so-called democratic racism (Buraschi and Aguilar Idáñez, 2019). However, the danger of these phenomena lies precisely in the consequences that discrimination and social isolation have on these women, by relegating them to situations in which they are discriminated against in areas such as employment, among others.

These differences can persist if they refuse to assimilate, in particular when visible racial and religious differences give rise to discrimination and exclusion (Tölölyan, 2007). These ethnic boundaries (or differences) are symbolic. That is, "conceptual distinctions made by social actors to categorise objects, people, practices and even time and space" (Lamont and Molnár, 2002, p. 168); and they must be differentiated from social borders, which "are materialised forms of social differences manifested in unequal access and unequal distribution of (material and immaterial) resources and social opportunities" (Lamont and Molnár, 2002, p. 168). Here the question would be how symbolic borders can lead to the establishment of social borders.

In general, and from the point of view of the classical theories of assimilation, the longer the residence time, the higher the level of social integration and advancement we would expect; and the more the second generation better identifies and integrates with the society of residence than the first generation. But the local structure of opportunities conditions the adaptation of these generations to their respective social contexts, along with other factors. If this structure does not facilitate the integration of these individuals, the separation between the minority and majority groups intensifies (Esman, 2009, p. 100).

Therefore, and in keeping with the bi-directional aspect of the integration process, it is essential to bring about not only a change in how the public imagines the cultural composition of current societies, but also in how to design public policies that help to integrate different cultural groups and to correct the different types of racism that are present in societies that receive immigration.

Regarding the regional social planning involving immigration, this first materialised in the Canary Islands through the Immigration Plan of the Canaries, approved in 2002. However, this Plan did not lay out a concept for integration or a model to follow, given the problems in reaching a political and administrative consensus in this area at the time (Kuehn, 2007). Of note is the existence of the Canarian Immigration Forum, created in 2000 and still active, which was created as a participatory, consultative and advisory body of the Government of the Canary Islands, and which brings together key political and social agents in this matter.

That same year, 2002, the Canary Islands Pact on Immigration was signed by various political forces, which adopted several agreements on immigration, basically involving the need to control the arrival of immigrants by irregular means, ensure their rights and promote intercultural values in Canarian society. However, the pact places greater emphasis on the first element: the arrival and reception of immigrants.

The first Plan was followed by a second one, the 2nd Immigration Plan 2006-2008, which mentioned young immigrants, and not just unaccompanied foreign minors, for the first time and which took a further step in that it attempted to go beyond just the assistance services considered in the first plan by also considering the necessary awareness of the host society as a key agent in the integration of the foreign population and cultural diversity. 


\section{In conclusion}

Taking the data collected here on births in the Canary Islands for the year 2018, we can conclude that an estimated $18.2 \%$ of the births produced that year involved foreign or mixed couples (in which one of the parents is a foreign national). $25.5 \%$ of all people born since 1999 in the Canary Islands of foreign origin (with at least one parent being a foreign nation) are currently between 0 and 4 years old; $28.2 \%$ are between 5 and $9 ; 28 \%$ are between 10 and 14 ; and $18.3 \%$ are between 15 and 19 .

This reflects the fact that the years with the highest number of births were 2008 and the years immediately after. Although in 2008 the highest number of births were to mothers of American origin, probably from the Latin American countries most represented in the Canary Islands, in 2018 the highest numbers of births were of European Community origin, which is consistent with this group's larger presence in the archipelago, followed by those of American origin, then African and Asian. As they have the largest foreign populations, the islands that register the most births are Tenerife and Gran Canaria.

In summary, we can state that the study of second generations is normally done in comparative terms with that of the previous generation in order to analyse how they are integrating into the host society. As a result, the publications that address this issue usually consider a socio-structural perspective, that is, analysing their social status. There are other types of works that also focus on identity issues and the discrimination experienced by groups of foreign origin.

However, empirical studies are still scarce in Spain in general, and in the Canary Islands and Tenerife in particular. It is true that some decades will still have to pass before their trajectories fully play out (when these young people enter the labour market), but some percentage of the population of foreign origin can already give us a considerable amount of information on how these generations are integrating into the educational system, what results they are achieving, if they experience discrimination and how they self-identify. There are even studies from an intersectional perspective of gender, class, ethnicity and other aspects. As we saw in the analysis of the Canarian case with the PISA data, there seems to be a downward integration ${ }^{6}$ of the immigrant population in the Canary Islands (ÁlvarezSotomayor, Gutiérres Rubio and Martínez-Cousinou, 2018).

In education, for example, the Education Act includes interventions with students of foreign origin through language support, insertion classes and intercultural education. However, intercultural education is not usually integrated into the school curriculum; rather, it is part of the specific actions that are left to the discretion of the schools and where oftentimes cultural differences are extolled through "Heritage Day" celebrations as something exceptional, but not as an aspect that coexists within the framework of our own social environment.

In this regard, it is necessary to generate data on how well second generations are integrating in comparison to previous generations in order to understand how they are evolving, both educationally and professionally. We should not, however, focus solely on structural studies, which analyse social positions, but also on those that rely on an intersectional approach to consider other relevant issues that have been addressed in this document, such as experiences with discrimination. This involves, depending on the origin, the social

6 For a more detailed and updated analysis of the socioeconomic conditions of the population of the Canary Islands, see the study on Migraciones, desigualdad e integración en tiempos de crisis by Godenau \& Buraschi (2017) 
class and gender, as well as identity markers (especially phenotypic traits and clothing), and also taking into account the spaces where they occur as well as the consequences that said experiences entail; identity issues, meaning these studies address how second generations self-identify in terms of their different groups of belonging and reference; their expectations; and, in general, how these individuals view their life experiences so that we can better identify the integration and exclusion mechanisms that are present in the current context of Canarian society.

Information in these areas is needed to guide public policies that, until now, have not materialised into concrete actions where cultural diversity is regarded as a constitutive element of society itself, at a time when more and more of the Canarian population was born into families of foreign origin. Public policies should not ignore these issues, in light of the negative results that experiences involving discrimination or social exclusion can have (see the French example), and especially of how racism and discrimination are the main obstacles faced by immigrants and their families in destination societies - societies that descendants consider as their own by virtue of having been born in them, and whose aspiration to integrate, greater than those of their parents, can be cut short by discriminatory experiences.

\section{For more information}

AIXELÁ CABRÉ, Y. (2001). “¿Qué nos ofende de los 'moros'? Discurso sobre los musulmanes y sus prácticas sociales", Scripta Nova. Revista Electrónica de Geografía y Ciencias Sociales, 94(59).

ÁlVAREZ-SOTOMAYOR, A., GUTIÉRRES RUBIO, D. \& MARTíNEZ-COUSINOU, G. (2018). ¿Desventaja académica de los hijos de inmigrantes? La excepción canaria en el contexto español. Revista Española de Sociología, 27(1), pp. 83-106.

APARICIO GÓMEZ, R. (2007). Las segundas generaciones en España: marroquíes, dominicanos y peruanos, Cuadernos Europeos de Deusto, 36, pp. 19-56.

APARICIO GÓMEZ, R. \& TORNOS CUBILLO, A. (2007). Hijos de inmigrantes que se hacen adultos: marroquíes, dominicanos y peruanos. Ministry of Labour and Social Affairs.

BURASCHI, D. \& AGUILAR IDÁÑEZ, M.J. (2019). Racismo y antirracismo. Comprender para transformar. Universidad de Castilla-La Mancha.

CACHÓN RODRÍGUEZ, L. \& LÓPEZ SALA, A. (COORDS.) (2007). Juventud e Inmigración, Desafíos para la Participación y para la Integración. General Directorate of Youth Affairs of the Employment and Social Affairs Council of the Government of the Canary Islands.

CARRASCO, S., PÀMIES, J. \& NARCISO, L. (2018). Abandono escolar prematuro y alumnado de origen extranjero en España ¿un problema invisible?, Anuario CIDOB de la Inmigración 2018, pp. 212-236. 
DOMINGO, A. \& BAYONA, J. (2007). Perfil sociodemográfico de los jóvenes de nacionalidad extranjera en España y las Islas Canarias. In Cachón Rodríguez, L. \& López Sala, A. (Coords.) (2007). Juventud e Inmigración. Desafíos para la Participación y para la Integración, pp. 12-26. General Directorate of Youth Affairs of the Employment and Social Affairs Council of the Government of the Canary Islands.

ESMAN, M. J. (2009). Diasporas in the Contemporary World. Cambridge: Polity.

FARIÑA ÁlVAREZ, J \& OBITEN, (2007). Proyecto Involve. Participación de inmigrantes en actividades de voluntariado para mejorar la integración. In Cachón Rodríguez, L. \& López Sala, A. (Coords.) (2007). Juventud e Inmigración, Desafíos para la Participación y para la Integración, pp. 260-270. General Directorate of Youth Affairs of the Employment and Social Affairs Council of the Government of the Canary Islands.

GARCÍA BORREGO, I. (2003). Los hijos de inmigrantes como tema sociológico: la cuestión de "la segunda generación, Anduli: revista andaluza de ciencias sociales, 3, pp. 27-46.

GODENAU, D. \& BURASCHI, D. (coords.) (2017). Migraciones, desigualdad e integración en tiempos de crisis. Island Council of Tenerife. Office of Employment, Trade, Industry and Economic Development.

GOFFMAN, E. (2006). Estigma. La identidad deteriorada. Buenos Aires, Amorrortu.

HEATH, A. (2014). "Introduction: Patterns of generational change: convergent, reactive or emergent?", Ethnic and Racial Studies, 37(1), pp. 1-9.

KHAN, S. A. (2011). "Location Nowhere: Alienation, Nihilism and Radicalism among British Pakistani Muslim Youth". In: David, M. \& Muñoz-Basols, J. eds. Defining and Re-defining Diaspora. From Theory to Reality. Oxford: Inter-Disciplinary Press.

KUEHN DUMPIÉRREZ, R. (2007). ¿Jóvenes o inmigrantes? Inmigración, juventudes y planificación social en Canarias. In Cachón Rodríguez, L. \& López Sala, A. (Coords.) (2007). Juventud e Inmigración, Desafíos para la Participación y para la Integración, pp. 64-90. General Directorate of Youth Affairs of the Employment and Social Affairs Council of the Government of the Canary Islands.

LAMONT, M. \& MOLNÁR, V. (2002). "The Study of Boundaries in the Social Sciences", Annual Review of Sociology, 28, pp. 167-195.

PARK, R. E. (1930). "Assimilation, Social". In: Seligman, E. \& Johnson, A. (eds). Encyclopedia of the Social Sciences.

PORTES, A., APARICIO, R. \& HALLER, W. (2009). La segunda generación en Madrid: un estudio longitudinal. Real Instituto Elcano, ARI 67/2009.

PORTES, A. \& APARICIO, R. (2013). Investigación longitudinal sobre la segunda generación en España: reporte de avance. ARI 34/2013. Real Instituto Elcano.

PORTES, A., APARICIO, R. \& HALLER, W. (2018). Hacerse adulto en España. La integración de los hijos de inmigrantes. Anuario CIDOB de la Inmigración 2018, pp. 148-181. 
PORTES, A. \& RUMBAUT, R. (2001). Legacies. The Story of the Immigrant Second Generation, California University Press.

PORTES, A. \& ZHOU, M. (1993). The New Second Generation and Its Variants, Annals of the American Academy of Political and social Science, 530, pp. 74-96.

PORTES, A., VICKSTROM, E. \& APARICIO, R. (2013). Hacerse adulto en España. Autoidentificación, creencias y autoestima de los hijos de inmigrantes. Papers, 98(2), pp. 148-181.

RAMÍREZ, A. \& MIJARES, L. (2005). Gestión del Islam y de la Inmigración en Europa: Tres estudios de caso, Migraciones, 18, pp. 77-104.

RUMBAUT, R.G. (2008). "Reaping What you Sow: Immigration, Youth, and Reactive Ethnicity", Applied Developmental Science, 12(2), pp. 108-111.

SARABIA MEDEL, J. (DIR.) (2007). Evaluación e investigación educativa. Inmigración, escolarización y Educación Intercultural en Canarias. Características sociales y académicas del alumnado inmigrante de Educación Infantil, Primaria y Secundaria Obligatoria. Council of Education, Culture and Sports of the Government of the Canary Islands.

TÖLÖLYAN, K. (2007). "The Contemporary Discourse of Diaspora Studies", Comparative Studies of South Asia, Africa and the Middle East, 27(3), pp. 647-655.

How to cite this article:

CABRERA ABU, N. (2020). Las Segundas Generaciones de Origen Extranjero. OBITen Factsheet 9-2020. Retrieved from www.obiten.net. DOI: https://doi.org/10.25145/r.obitfact.2020.04.

The Tenerife Immigration Observatory is a joint initiative of the Tenerife Council and the University of La Laguna that is intended to provide a permanent and dynamic structure to advance our scientific knowledge of migratory movements. The OBITen carries out its activity by gathering, producing and disseminating knowledge to facilitate qualified opinions and promote the making of decisions that help to better manage migratory phenomena and their implications.

http://www.obiten.net 